\title{
Environmental Impacts of Commercial Shrimp Farming in Coastal Zone of Bangladesh and Approaches for Sustainable Management
}

\author{
Shahriar abdullah*, Dhrubo Barua and Md Sazzad Hossain \\ Department of Environmental Science and Disaster Management, Noakhali Science and Technology University, Bangladesh
}

Submission: June 01, 2019; Published: July 15, 2019

*Corresponding author: Shahriar Abdullah, Department of Environmental Science and Disaster Management, Noakhali Science and Technology University, Bangladesh

\begin{abstract}
Shrimp cultivating in Bangladesh has been accelerated quickly following huge demand in the global market. Since the mid-1980s, shrimp is a significant part of the economy of Bangladesh. This practice is growing in Bangladesh because of favorable agro-climatic conditions, sufficient water resources, cheap labor, and international donor agencies. Despite a range positive factor like foreign exchange, employment and food, the industry has terrible environmental impacts. This spontaneous and indiscriminate shrimp cultivating is gathering impressive discourse because of its negative ecological results. Environmental effects like mangrove destruction, sedimentation, saltwater interruption, loss of biodiversity and contamination are seen to be the key obstructions for the advancement of sustainable shrimp cultivating. A large number of sections of land of terrains in the seaside territories have been included under shrimp cultivation. Unplanned and haphazard growth of shrimp culture has an influence on the coastal ecosystem. This paper has the aim to focus on how the shrimp farming in Bangladesh is affecting the soil, water, crop production, the mangroves, and the coastal biodiversity. This paper has intended to concentrate on how the shrimp cultivating in Bangladesh is influencing the water, soil, crop production, mangroves, and the coastal biodiversity.
\end{abstract}

Keywords: Aquaculture; Shrimp farming; Environment; Coastal zone; Bangladesh; Sustainable culture

\section{Introduction}

Shrimp cultivating is one of the snappiest developing financial exercises in coastal zones of the Asia-Pacific locales, contributing more prominent than $85 \%$ of world's cultivated shrimp, where Bangladesh is the fifth biggest maker on the planet [1]. Because of the positive atmosphere and accessibility of room, shrimp aquaculture has grown for the most part in tropical and subtropical coastal lowlands. It is the third biggest remote exchange winning product of Bangladesh, after garment and jute, shrimp contributing $9 \%$ to countrywide fare benefits [2]. These days, shrimp is the second most significant fare things in Bangladesh. Accordingly, shrimp cultivating ended up one of the key monetary exercises in various seaside areas. It is much of the time named as 'blue revolution' [3]. The crucial shrimpcreating regions are Bagerhat, Satkhira, Pirojpur, Khulan, Cox's Bazar and Chittagong [4]. As per the actualities from the Department of Fisheries of Bangladesh [5], the exported amount of solidified shrimp was once 15,023 tons in 1988, which was multiple times higher (47,879.91 tons) in 2011. Ongoing figures prescribe that around 15 million individuals in Bangladesh are straightforwardly or in a roundabout way depend on the shrimp and prawn cultivating [6].
Aquaculture is one amongst the quickest growing animal food-producing sectors around the world, with yearly increment averaging $6.1 \%$ for 2002-2012 [7,8]. Aquaculture presently accounts for pretty much $50 \%$ of the world's sustenance fish [9]. Aquaculture practice for food fish in Asian country is shown within the Figure 1.

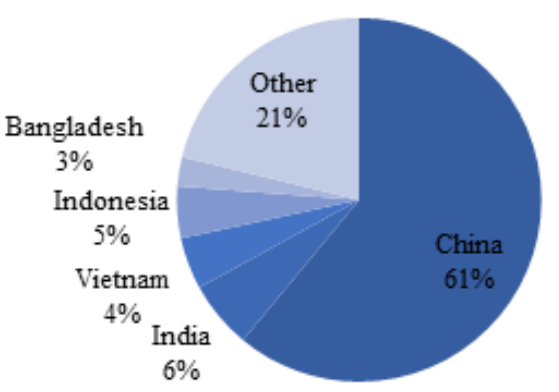

Figure 1: Food fish produced by aquaculture in Asian country [8]. 
The territory utilized for shrimp cultivation in Bangladesh has raised from around 20,000 ha in 1980 to just about 244,000 ha in 2014 [10]. The 2 shrimp species: Penaeus monodon (black tiger shrimp; native name: Bagda) and Macrobrachium rosenbergii (freshwater prawn; native name: Golda), are named "white gold" because of the fact of their excessive cost [11].

This indiscriminate and impromptu system of shrimp cultivating has harming outcomes each on environment and society [12]. The negative effects of shrimp cultivating have emerged from a lack of common sense and management practices, also as a weak application of these laws. Objections are normally related with environmental consequences (loss of mangroves and its related biodiversity, disintegration of soil and water quality, loss of agro-biodiversity and fish, saltwater interruption, diminish in neighborhood assortment of rice and fish, disease outbreak and pollution), social clashes, and negative impact on the economic system due to decline land for crop production $[13,14]$. Shrimp cultivating development in Bangladesh is commonly unregulated, uncontrolled and uncoordinated [15-17].

This paper, principally based on basically secondary published literature, reviews the development, manufacturing patterns, function and culture examples of shrimp cultivating coastal zone of Bangladesh. The foremost expectation of the diagram is to give a firm establishment to propelling aptitude on the ecological effects of shrimp cultivating. At long last, this review will prompt an observational practicality investigation of the management approach for sustainable shrimp cultivating in Bangladesh, recent technologies to mitigate impacts, for desirable management of the coastal region and sustainable shrimp cultivation in Bangladesh.

\section{Shrimp Culture in Asian Country History}

For a long time, the people of Bangladesh (once area of Bengal in pre-parcel India and of Bangladesh from 1947 to 1971) include connected inside the vast water catch of inland and marine finfish and the cultivation in perennial and seasonal tanks and lakes [18]. By 1940 the government of Bengal had made proposals to improve the shut way of life fisheries, comprising of shrimp, and there will not to be a local trade in open catch shrimp from coastal estuaries with Myanmar and East Bengal. By 1945 broil and produce were raised by government exports available authorities for sale [19]. The Pakistan Government paid constrained interest to shrimp manufacturing in the course of the 1950s, however, two factories had been set up in 1954 to export frozen and canned shrimp to the USA and Western Europe and in 1959 the first shrimp and fish processing and freezing plant was installed. By 1970, there were five fish canning plants in Chittagong engaged in the freezing of prawn and frog legs [20]. By the mid-1960s, wild shrimp (22 species) are being sold for the domestic market both fresh and preserved by boiling and sun-drying and smoking [21]. During the 1970s, shrimp aquaculture in Bangladesh was begun in ghers (pond) [22]. However, this framework has developed over time.

Existing Shrimp Farming Trend and Pattern in Bangladesh

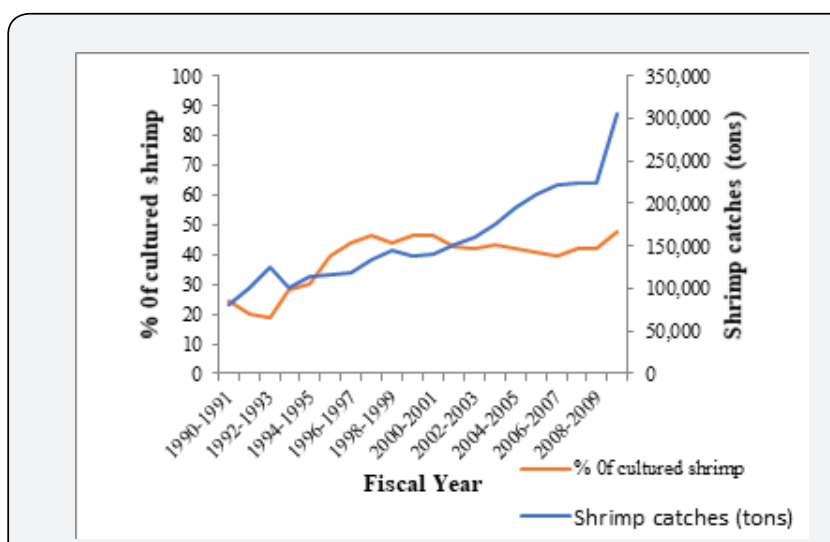

Figure 2: Yearly shrimp production and percentage of cultured shrimp contribution in shrimp aquaculture in Bangladesh [23].

Within the coastal zones of Bangladesh, Shrimp aquaculture has risen from the south-eastern towards the south-western parts. At first, the pond vicinity under shrimp aquaculture included 20,000 ha in 1980 , developing quickly to around 217,877 ha in 2007/08 [23]. Export of shrimps between 1995 and 1996 fiscal year earned US\$270 million. Somewhere in the range of 2010 and 2011, the amount raised up to US $\$ 449.56$ million [24]. Two zones in the south, the Chittagong-Cox's Bazar belt and Khulna, Satkhira-Bagerhat belt, represent 95\% of the complete area of shrimp culture in the country [25]. Yearly shrimp production in tons and percentage of cultured shrimp contribution of shrimp aquaculture in Bangladesh (19981999 to 2007-2008) are appeared in Figure 2. Total shrimp manufacturing takes place from three sources; inland capture, inland culture, and marine fisheries.

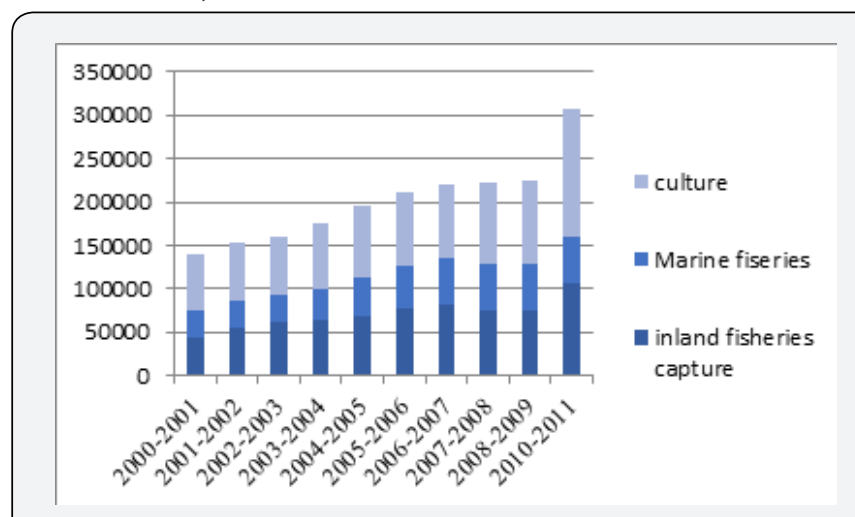

Figure 3: Total yearly shrimp capture from culture, inland and marine sources [24].

(Figure 3) Bangladeshi shrimp development is frequently classified into 4 classifications: traditional, extensive, semiintensive and intensive based on the intensity of the culture pattern like stocking density, inputs (feed, fertilizer), seed supply, range of species, production cost and water exceptional 
management [12,27]. In Bangladesh, $70 \%$ of the shrimp farms use typical and/or intensive, $25 \%$ semi-intensive, and $5 \%$ intensive culture methods [28].

\section{Factors Responsible for Expanding Commercial Shrimp Farming}

Various chronological historic exercises had been identified with the development of industrial shrimp cultivating in Bangladesh as a result of developing a worldwide interest of shrimp items, the industry was expanding incredibly in a haphazard manner. Following sections provide an explanation for the principal factors responsible for emergence of industrial shrimp farming in Bangladesh.

\section{Environmental Impacts of Unregulated Shrimp Farming}

Table 1: The impacts of shrimp farming on the environment, ecology and society of Bangladesh.

\begin{tabular}{|c|c|c|c|c|c|c|c|c|c|}
\hline Impacts & $\begin{array}{c}\text { Fry } \\
\text { Catching }\end{array}$ & $\begin{array}{c}\text { Fry } \\
\text { Import }\end{array}$ & $\begin{array}{c}\text { Pound } \\
\text { Construction }\end{array}$ & $\begin{array}{c}\text { Feed } \\
\text { Waste }\end{array}$ & $\begin{array}{c}\text { Water } \\
\text { Exchange }\end{array}$ & Antibiotics & $\begin{array}{l}\text { Lime and } \\
\text { Fertilizer }\end{array}$ & Disease & $\begin{array}{c}\text { Overall Shrimp } \\
\text { Farming }\end{array}$ \\
\hline Water Quality & $*$ & $*$ & $\# \#$ & \#\# & \#\# & \#\# & $\#$ & \#\# & $\#$ \\
\hline Salt Intrusion & $*$ & $*$ & \#\# & $*$ & $*$ & $*$ & $*$ & $*$ & \#\# \\
\hline $\begin{array}{c}\text { Mangrove } \\
\text { Destruction }\end{array}$ & $\#$ & $*$ & \#\#\# & $*$ & $*$ & $*$ & $*$ & $*$ & \#\# \\
\hline Biodiversity Loss & \#\# & $\#$ & \#\# & \#\# & \#\# & $\#$ & $\#$ & \#\# & \#\# \\
\hline Soil Erosion & $*$ & $*$ & \#\# & $*$ & $\#$ & $*$ & * & $*$ & $\#$ \\
\hline Calamity & $*$ & $*$ & $\# / *$ & $*$ & * & $*$ & $*$ & $*$ & $\#$ \\
\hline Soil Acidity & $*$ & $*$ & \#\# & * & \#\# & * & $*$ & * & $\#$ \\
\hline Hydrology & $*$ & $*$ & $\# \#$ & $*$ & $*$ & $*$ & $*$ & $*$ & $\#$ \\
\hline Eutrophication & $*$ & $*$ & $\# / *$ & \#\# & \#\# & $*$ & \#\# & $*$ & $\#$ \\
\hline Rice Production & * & * & $\# \#$ & $*$ & \#\# & * & $*$ & * & \#\# \\
\hline
\end{tabular}

*: No impact, \#: Low impact, \#\#\#: Strong impact; sources: [3,12,13,35].

The rapid increase of shrimp cultivating has prompted both short and long-term terrible environmental impacts, counting biological imbalance, environmental contamination and disease spread. This has furthermore caused a steady decrease in other agricultural and homestead crops, several fruit and woody trees, and homestead vegetables [34]. These bad outcomes, in the end, accelerate the changes in both aquatic and terrestrial environment, biodiversity and biological systems. Thus, shrimp cultivating is facing the management related challenges which lead to more noteworthy worries about water quality, feed, and seed supply (Table 1).

The unplanned and unregulated shrimp farming ultimately gave rise to numerous socio-economic and ecological impacts. A few instances are cited below:

\section{Destruction of the mangrove ecosystem / Destruction of mangroves and related impacts}

From historical records, it is evaluated that over half of the world's original mangrove cover has been destroyed [36]. Mangrove destruction in the world is caused by means of two factors: aquaculture and horticultural development as well as industrial and settlement improvement [37]. Quite a bit of this a) Suitable biological and climatic conditions of coastal areas [29].

b) Price rise in the worldwide market [30].

c) Response to global demand [30].

d) The accessibility of resources, for example, feed, seed, water, and shoddy work power [31].

e) Cheap land and labor [32].

f) Victim of a "Green Revolution" [30].

g) Availability of shrimp fry [22].

h) Increased funds from international donors [33]. destruction has occurred in current decades [38]. Bangladesh has the world's biggest mangrove (locally referred to as Sunderban, meaning beautiful forest) in the south-west shore of the country. The mangroves are exceptionally wealthy in biotic variety supporting around 330 types of plants, 400 types of fishes, around 40 types of shrimps and various shellfish, and 35 types of reptiles [39]. It plays a significant function in the coastal ecology serving as a nursery ground for marine fisheries, defending coastal shores from erosion and storm damage [40]. But several shrimp ponds have been developed close by the fringe of Sundarbans mangrove. Shrimp culture is nowadays regarded as the silent destroyer of mangrove round the world, between $30 \%$ and $70 \%$ of the mangrove region has been lost due to shrimp farming [41].

The definite rate of mangrove destruction in light of the constructing of ponds within the south-western parts of Bangladesh is not yet familiar. In any case, in the south-eastern parts of Bangladesh, an area of 18,200 ha of mangrove (Chakaria Sundarbans) has almost totally been destroyed to make room for shrimp aquaculture [42]. The find out about of Shahid and Islam revealed that about 9,734 ha of mangrove have been lost in the southeastern part could be directly attributed to shrimp culture 
[43]. Without considering these irreversible long long-term effects on the coastal ecology, huge annihilation of mangrove has been carried out in Bangladesh for the sake of the progress of shrimp culture [44,45]. A present report by Swapan \& Gavin (2011) in southwestern Bangladesh observed that the shrimp cultivating had changed almost $90 \%$ of agricultural land and mangroves into shrimp farms [30].

Mangrove removal might also cause coastal erosion, alterations in sedimentation patterns and shoreline configuration. However, shrimp aquaculture is not the only reason for mangrove degradation; other land uses, for example, rice production and salt manufacturing have also played a widespread function in the destruction of mangrove forests in Bangladesh [3].

\section{Wild fry catch, imported fry and decline in biodiversity}

The demonstration of transporting shrimp seeds from various geographic territories has brought about the introduction of five of the six perceived penaeid shrimp infections. The bringing in of shrimp seeds without isolation has spread different viral and contagious maladies all through Bangladesh [3]. Shrimp cultivation farms in Bangladesh stock wild-caught juveniles instead of hatchery-reared post larvae that result in loss of biodiversity. Although hatchery post-larvae are now handy in many countries in Asia and Latin America, wild fry still provides the key supply of seed in others. Trawl fishermen collect mother shrimps as brood stock from the deep ocean that performs a principal function in the loss of fisheries [46]. When the shrimp industry uses maritime fish as trash fish to create fish meal, and eventually to produce pellet feed, it diminishes the wild fishery resources [47]. Catches of wild shrimp in both open sea and coastal ecosystems have declined because of overexploitation and contamination in the coastal region [48].

\section{Water and nutrient pollution}

The low-quality feed is the major pollution source of the shrimp cultivating and its adjoining waters [49]. Effluents from shrimp ponds are typically enriched in suspended solids; nutrients like ammonia, nitrate, nitrite; chlorophyll and biochemical oxygen demand (BOD) [50,51]. Organic trashes from fish or shellfish farming incorporate leftover food, body wastes and dead fish. Nutrient pollution has additionally been found to originate the amplified growth of certain species of phytoplankton, with some that are recognized to cause unfavorable algal blooms and increase fouling. Intensive shrimp farming needs a consistent change of water, about $5-10 \%$ of the whole pond extent per day during earlier, and $30-40 \%$ throughout later stages of the growth period [52]. The discharging effluents can decrease the dissolved oxygen, create hypernutrification and eutrophication, increase sedimentation load, and cause modifications in the benthic communities [53].

\section{Sedimentation}

Water runoff all through the rainy season comprises of sediments from upstream through river tributaries to coastal areas [54]. Once water from estuaries or river channels is stored in shrimp ghers or ponds, the sediments quickly settle on the bottom as water velocity slows down [54]. Management practices, which incorporate high stocking density, feed application, aerator use, liming and composts, and so on, also add to suspension and sediment accumulation [55]. The pond bottom accumulates excessive organic substances like nutrients (nitrogen, phosphorus and ammonia) and hydrogen sulfide that creates foul odors, hypernutrification and eutrophication [55]. Shrimp farming increments suspended solids or colloids that produce turbidity, decreases daylight penetration into the water segment. Turbidity is reported at $23 \%$ to intensive farms and at 39\% semi-intensive farms in Bangladesh [13] (Figure 4).

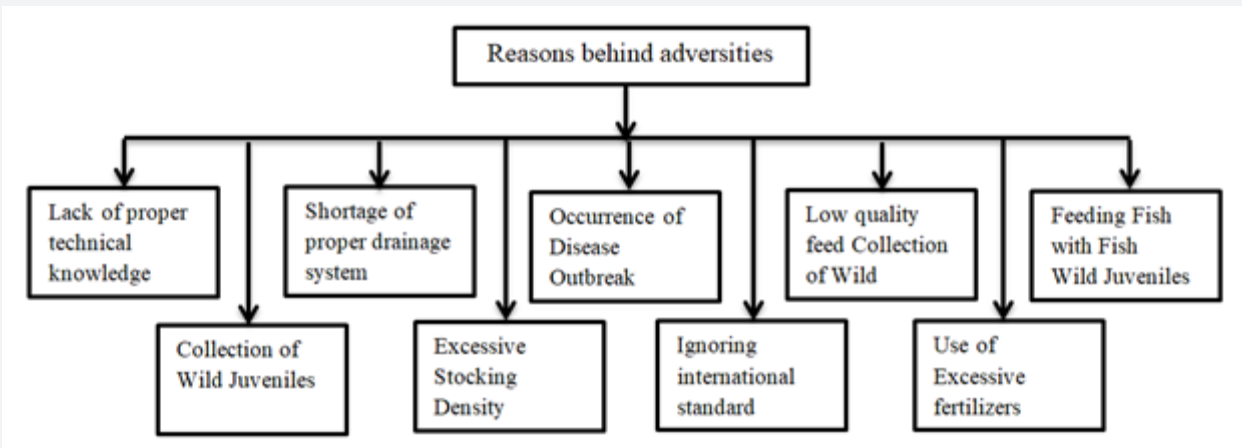

Figure 4: Reasons behind the adversities in shrimp farming in Bangladesh [56].

\section{Saltwater intrusion}

The effect of the unregulated growth in shrimp farming on whole ecosystems is not confined to mangroves. In the southwestern parts of Bangladesh, salinization lessens water supplies for shrimp farming as well as for drinking, household wants and irrigation [3,57]. Shrimp cultivation has raised serious subject regarding the impact of seawater intrusion into the surrounding agricultural lands $[53,58]$. Ponds are being built for shrimp cultivation behind mangrove forests wherever freshwater wetlands and rice-growing areas still exist $[52,58]$. Saltwater intrusion has brought on issues in terms of severely reduced supplies of potable freshwater, which again has led to 
extend of waterway contaminations as well as the loss of various crops, poultry, and fodders [59]. There the freshwater wetlands and rice-growing areas are affected by surface and subsurface saltwater intrusion generated by the new ponds [58].

\section{Diseases}

Intensive farming makes the shrimps exceptionally liable to diseases [60]. Some number of the diseases that trouble the shrimp farming business area unit straightforwardly caused by environmental issues. Bangladesh has experienced disease outbreak in each semi-intensive and extensive farm in 1996 [61]. when physicochemical factors like $\mathrm{pH}$ scale, temperature, dissolved oxygen, pH scale, etc. vary every now and again, shrimps become vulnerable to stress, bringing about diseases [48] like red color, soft shell, tail rot and black gill [60,61]. High stocking density and excessive use of feed lower water quality that contributes to fret and diseases among shrimp in intensive farming systems. In 1996, Bangladesh lost $44.4 \%$ of its complete shrimp production due to White Spot Syndrome Virus (WSSV) [62].

\section{Use of antibiotics, medicine, and other chemical products}

Shrimp aquaculture in Bangladesh depends intensely on the input of artificially formulated feed and the application of the disinfectants, water, and soil treatment components, algicides, and pesticides, and feed added substances. These items are much of the time utilized in shrimp ponds to treat water and dregs sediment as well as to prevent disease and sanitize hardware. Prefuran, the manufactured specialists frequently utilized as anti-infection agents in incubation centers are chloramphenicol, erythromycin, oxytetracycline, Furazolidone [63]. A few synthetics utilized in shrimp cultivating, as organotin mixes, copper mixes, and toxic residues, are probably going to badly affect the environment [64]. The typically used disinfectant chlorine is applied to kill microorganisms. Further pesticides are applied in shrimp ponds to kill unwanted organisms like fish, crustaceans, snails, fungi, and algae [64]. As pond management is becoming tougher over the course of time, the utilization of chemicals is gradually increasing.

\section{Salinity intrusion in water and soil layers and impact on agriculture}

Shrimp farming affects soil and water quality in the cultivated land. The release of saline water from shrimp ponds additionally increases the salinity in neighboring agricultural lands [65]. The southwestern Bangladesh the mean values of water salinity at the low, medium and high saline zones were 1.2 and 1.64, 4.25 and 5.14, 9.75 and $9.17 \mathrm{ppt}$, respectively [66]. The central snag to strengthening of harvest generation is regularly high substance of salts in the root area of the soil. Prolonged inundation inhibits the fixation of free nitrogen and halts mineralization, therefore impairing soil fertility [13]. The flow of excessive saline water usually enters into the plants by osmosis. Consequently, the plants have been suffered from starvation of water and created physiological drought conditions $[67,68]$.

\section{Destruction of the local ecosystem}

The procedure of shrimp farming in southwestern Bangladesh used to pulverize the natural environment, ecosystems and social frameworks $[69,70]$. Aquaculture production of shrimp becomes the foremost relentless destroyer of massive areas of tropical wetlands. Variety of shrimp ponds developed alongside the periphery for catching shrimp fry shrinks the reserve location of the mangrove forest 'Sundarbans.' The severe fishing strain grasps shrimp fries as well as other vital revering species that spawn within the coastal regions. It destroys the environment of the coastal ecosystems as well [71] (Figure 5).

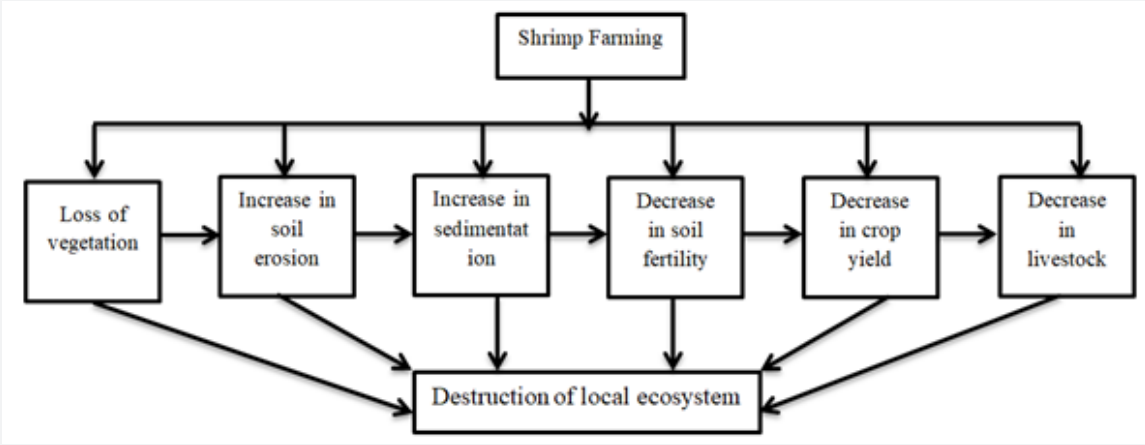

Figure 5: Negative shrimp farming impacts on ecosystem [72].

\section{A Reformist View to Solve the Problem}

Regarding cost selected per hector, well-managed shrimp farming is the most profitable sort of land use within the coastal zones of Bangladesh. Overall, it has furnished the country with an essential possibility for monetary improvement at the macrolevel. However, that does not legitimize the environmental and socio-economic charges within the long-term. Toufique
[73] Mentioned three totally different perspectives identifying with the appropriate response of this complicated problem [73]. These are pessimistic, optimistic and a reformist view. Pessimistic view: Shrimp cultivating is unsustainable because of the negative externalities are precise, endemic, and irreversible. Therefore, shrimp farming has got to be prohibited. Optimistic view: Shrimp generates a financial gain, employment, and 
overseas trade accordingly the advantages exceed the associated costs. Reformist view: There are negative environmental and social externalities. However, that can be dealt with via policy intervention. This is often a moderate view making an endeavor to limit the considerations.

At the national policy level of Bangladesh, the typical perception is that shrimp farming is not any more drawn out the fundamental reason for ecological degradation. It is the haphazard and impromptu methodology of shrimp farming that is more accountable for environmental and social degradation of the coastal community [73]. In the coastal Zone Policy of 2005, the policy framework mentioned that the authorities will take positive measures to comprehend the targets of poverty reduction through rising economic growth within the coastal zone in such manner 'accessible potentialities of the coastal area are going to be used via sustainable management by means of investment in shrimp culture' [74]. Therefore, the authorities of Bangladesh will not keep the intense views that shrimp farming can persist unabated (optimistic view) or ought to be halted in places (pessimistic view). Rather sustainable management for shrimp farming has been motivated to decrease environmental losses and its social impacts, mirroring the reformist view. Such a view needs a radical analysis of the current restrictive and institutional framework to make sure sustainable shrimp farming within the country [75].

\section{Moving towards More Sustainable Aquaculture Systems}

In sequence for aquaculture strategy to shift inside the heading of sustainable yield, the industry needs few conditions to grasp and tackle the complete spectrum of environmental effects realized by its operations. Consecutively, this infers shifting near closed production frameworks. Potential answers for the challenges of aquaculture on the environment will be:

a) Integrated multi-trophic aquaculture (IMTA) - within which organic remaining items from the farmed species (finfish or shrimp) are exercised as supplements or nourishment by means that of various cultivated species.

b) Aquaponics - within which effluent remaining for fish farming are exercised as a nutrient supply for growing vegetables, herbs and/or flowers.

c) Lessening alimentation will drop expenses of food, condense nutrient accumulation and aid in conserving obligatory Dissolved oxygen ranges and increase herbivore fish.

d) Closed loop/ Recirculating Aquaculture System (RAS) can discourse water require, drain pollution and should utilize remarkable and multifaceted filtration systems.

e) Overstocking got to be alluded to lessen stress, decrease disease/pathogen outbreak, and lessen antibiotic usage, sell and purchase nearby, reduce transport footprint. f) Stock local species together with Organic aquaculture and ideal drainage facilities.

g) Producing quality seeds and supplying best feed at a competitive value

h) Improve transportation facilities and a decrease in the use of chemotherapeutics.

i) Ensure top quality raw materials whereas manufacturing meshed feed.

\section{Discussion and Conclusion}

Bangladesh has tremendous coastal and marine sources alongside its south edge. The coastal place of the country is perceived as one of the incredibly productive areas of the world. This is because of the reality of the geological position and climatic circumstance of the region. However, impromptu and unregulated coastal shrimp farming has emerged as the most unfavorable structure of resource use over the past couple of decades in Bangladesh. Once its environmental and social issues are considered, shrimp cultivating has not raised the farmers' expectation for everyday comforts. Though it's created temporary employment opportunities, the cost of destruction is a lot more than these advantages. Impromptu shrimp cultivating has various ecological punishments like high salinity in soils, soil and pollution and disease outbreak, public health hazard, mangroves destruction, loss of diverseness and nearby environmental modification. Resources such as feed, seed, and water supply influence the sustainability of shrimp aquaculture. Shrimp cultivating is anticipated to proceed with its extension with new domains being focused as old ones are depleted. In any case, it's anything but a maintainable sort of aquaculture. However, it is not a sustainable kind of aquaculture. A sustainability concept for an eco-friendly and socially appropriate farming and management system ought to be developed around the world to make sure the future. The long-haul advantages of shrimp cultivating can exclusively be performed by means of the improvement of ecologically reasonable shrimp cultivating. This will handle the ecological and financial issues produced by the method for shrimp cultivating and guarantee the survival of shrimp cultivating.

\section{References}

1. FAO (2014) The state of world fisheries and aquaculture, p. 243.

2. Mitro S, Khatun R, Baten MA (2014) Socio-economic and environmental impacts of shrimp culture in some selected areas of Bagerhat District. Environ Sci Nat Resour 7(1): 265-269.

3. Deb AK (1998) Fake blue revolution: environmental and socio-economic impacts of shrimp culture in the coastal areas of Bangladesh. Ocean Coast Manag 41(1): 63-88.

4. Belton B, Karim M, Thilsted S, Murshed-E-Jahan K, Collis W, et al. (2011) Review of aquaculture and fish consumption in Bangladesh: studies and reviews 2011-53. The World Fish Center.

5. Fisheries Resources Survey System (FRSS) (2012) Fisheries statistical yearbook of Bangladesh, vol 28. Department of Fisheries, Bangladesh. 
6. MFL (2014) National Shrimp Policy. Ministry of Fisheries and Livestock (MFL), Dhaka, Bangladesh.

7. FAO (Food and Agriculture Organization of the United Nations) (2014a) FAO yearbook 2012 fishery and aquaculture statistics. Rome: FAO.

8. FAO (Food and Agriculture Organization of the United Nations) (2014b) The state of world fisheries and aquaculture 2014. Rome: FAO.

9. Hishamunda N, Ridler NB, Bueno P, Yap WG (2009) Commercial aquaculture in Southeast Asia: some policy lessons. Food Pol 34(1): 102107.

10. Karim M, Meisner CA, Phillips M (2014) Shrimp (Penaeusmonodon) farming in the coastal areas of Bangladesh: Challenges and prospects towards sustainable development. In: Delaney CA (Ed.), Shrimp evolutionary history, ecological significance and effects on dietary consumption New York: Nova Science, pp. 57-88.

11. Islam MS (2009) In search of "White Gold”: Environmental and agrarian changes in rural Bangladesh. Society and Natural Resources 22: 66-78.

12. Paul BG, Vogl CR (2011) Impacts of shrimp farming in Bangladesh: challenges and alternatives. Ocean Coast Manag 54(3): 201-211.

13. Wahab MA (2003) Environmental impacts of shrimp farming in the coastal areas of Bangladesh. In: Wahab MA (Ed.), Environmental and socioeconomic impact of shrimp farming in Bangladesh, technical proceeding BAUNORAD workshop, 5 March 2002. BRAC Center, Dhaka, pp. 19-32.

14. Karim MR (2006) Brackish-water shrimp cultivation threatens permanent damage to coastal agriculture in Bangladesh. In: Hoanh CT, Tuong TP, Gowing JW, Hardy B (Eds.), Environment and livelihoods in tropical coastal zones. Wallingford: CAB International, pp. 61-71.

15. Metcalfe I (2003) Environmental concerns for Bangladesh. J South Asian Stud 24: 423-438.

16. Samarakoon J (2004) Issues of livelihood, sustainable development, and governance: Bay of Bengal. Ambio 33(1-2): 34-44.

17. Alam SMN, Lin CK, Yakupitiyage A, Demaine H, Phillips MJ (2005) Compliance of Bangladesh shrimp culture with FAO code of conduct for responsiblefisheries: a development challenge. Ocean Coast Manag 48(2): 177-188.

18. Bagchi A, Jha P (2011) Fish and fisheries in Indian heritage and development of pisciculture in India. Rev Fish Sci 19(2): 85-118

19. Rahman QM (1945) Tour note of Deputy Director of Fisheries (Administration), Bengal, for the month of July 1945. QM Rahman. Government of Bengal, Department of Agriculture, Fishing Branch, File No. 3M-78, 1945. Tour Note of the Deputy Director of Fisheries (Adm), Bengal.

20. Rivzi S (1970) East Pakistan district Gazeteers: Chittagong. Government of East Pakistan, Dacca.

21. Ahmed N (1967) Prawn and prawn fishery of East Pakistan. Government of East Pakistan, Directorateof Fisheries, Office on Special Duty, Services and General Administration Department In-charge, East Pakistan Government Press, Dacca.

22. Islam MS, Wahab MA (2005) A review on the present status and management of mangrove wetland habitat resources in Bangladesh with emphasis on mangrove fisheries and aquaculture. Hydrobiologia 542(1): 165-190.

23. DoF (2009) Fishery statistical yearbook of Bangladesh 2007-2008. In: Fisheries resources survey system. Department of Fisheries, Ministry of Fisheries and Livestock, $\left(25^{\text {th }}\right.$ edn), Matshya Bhaban, Dhaka, p. 42.

24. Uddin MB, Sultana T, Rahman MM (2013) Shrimp export marketing of Bangladesh. Bangladesh Res Publ J 8(2): 146-151.
25. Bhattacharya D, Rahman M, Khatun FA (1999) Environmental impacts of trade liberalization and of policies for the sustainable management of natural resources: a case study on Bangladesh's shrimp farming industry. Geneva.

26. Hossain MS, Uddin MJ, Fakhruddin ANM (2013) Impacts of shrimp farming on the coastal environment of Bangladesh and approach for management. Reviews in Environmental Science and Bio/Technology 12(3): 313-332.

27. Islam MS, Milstein A, Wahab MA, Kamal AHM, Dewan S (2005) Production and economic return of shrimp aquaculture in coastal ponds of different sizesand with different management regimes. Aquacult Int 13(6): 489-500.

28. Holmstrom K, Graslund S, Wahlstrom A, Poungshompoo S, Bengtsson BE, Kautsky N (2003) Antibiotic use in shrimp farming and implications for environmental impacts and human health. Int J Food Sci Technol 38(3): 255-266.

29. Chowdhury MA, Khairun Y, Salequzzaman M, Rahman MM (2011) Effect of combined shrimp and rice farming on water and soil quality in Bangladesh. Aquaculture International 19(6): 1193-1206.

30. Swapan MSH, Gavin M (2011) A desert in the delta: Participatory assessment of changing livelihoods induced by commercial shrimp farming in Southwest Bangladesh. Ocean \& Coastal Management 54(1): 45-54.

31. Islam MS (2003) Perspectives of the coastal and marine fisheries of the Bay of Bengal, Bangladesh. Ocean Coast Manag 46(8): 763-796.

32. Fleming C (2004) Challenges facing the shrimp industry in Bangladesh. Dhaka: American International School.

33. Bene C (2005) The good, the bad and the ugly, discourse, policy controversies and the role of science in the politics of shrimp farming development. Development and Policy Review 23(5): 585-614.

34. EJF (2004) Desert in the Delta: A Report on the Environmental, Human Rights and Social Impacts of Shrimp Production in Bangladesh. Environmental Justice Foundation (EJF), London, UK.

35. Primavera JH (1997) Socio-economic impacts of shrimp culture. Aquac Res 28(10): 815-827.

36. Kelleher G, Bleakley C, Wells S (1995) A Global Representative System of Marine Protected Areas, Volume 1.

37. Giri C, Zhu Z, Tieszen LL, Singh A, Gillette S, et al. (2008) Mangrove forest distributions and dynamics (1975-2005) of the tsunami-affected region of Asia J Biogeogr 35(3): 519-528.

38. WRI (2000) A guide to world resources 2000-2001: people and ecosystems: the fraying web of life. World Resources Institute, Washington, DC.

39. Hussain KZ, Acharya G (1994) Mangroves of the Sundarbans, Vol 2, Bangladesh. IUCN, Bangkok.

40. Landesman L (1994) Negative impacts of coastal tropical aquaculture developments. World Aquac 25(2): 12-17.

41. Barbier EB, Cox M (2004) An economic analysis of shrimp farm expansion and mangrove conversion in Thailand. Land Econ 80(3): 389-407.

42. Akhtaruzzaman AFM (2000) Mangrove forestry research in Bangladesh. In:Research for Conservation $m$ of Mangroves, International Workshop Asia-Pacific Cooperation, 26e30 March. Okinawa, Japan.

43. Shahid MA, Islam J (2003) Impact of denudation of mangrove forest due to shrimp farming on the coastal environment in Bangladesh. In: Wahab MA (Ed.), Technical proceedings of BAU-NURAD workshop on environment and socio-economic impacts of shrimp farming in Bangladesh. 5 March 2002. BRAC Centre, Dhaka. Bangladesh Agricultural University, Mymensing, pp. 67-75 
44. Rahman MM, Rahman MM, Islam KS (2010) The causes of deterioration of Sundarban mangrove forest ecosystem of Bangladesh: conservation and sustainable management issues. AACL Bioflux 3(2): 77-90.

45. The Sundarbans, Bangladesh (2011) World Heritage Sites: Protected Areas and World Heritage. United Nations Environment Programme and World Conservation Monitoting Centre.

46. Primavera JH (2006) Overcoming the impacts of aquaculture onthe coastal zone. Ocean Coast Manag 49(9-10): 531-545.

47. Naylor RL, Goldburg RJ, Primavera JH, Kautsky N, Beveridge MCM, et al. (2000). Effect of aquaculture on world fish supplies. Nature 405: 1017-1024.

48. Paez-Osuna F, Gracia A, Flores-Verdugo F, Lyle-Fritch LP, Alonso-Rodraguez R, et al. (2003) Shrimp aquaculture development and the environment in the Gulf of California ecoregion. Mar Pollut Bull 46(7): 806-815.

49. Yang QX, Jiang YW, Zhang XY, Yang Y (1999) Study on the effects of decomposition of the bait in a shrimp pond on the maricultural environment. Mar Environ Sci 18: 11-15

50. Barraclough S, Finger-Stich A (1996) Some Ecological and Social Implications of Commercial Shrimp Farming in Asia. UNRISD Discussion Paper 74. UNRISD (United Nations Research Institute for Social Development), Geneva, Switzerland, pp. 1-71.

51. Paez-Osuna F (2001) The environmental impact of shrimp aquaculture: causes, effects, and mitigating alternatives. Environ Manag 28(1): 131-140.

52. Flaherty M, Karnjanakesorn C (1995) Marine shrimp aquaculture and natural resource degradation in Thailand. Environ Manag 19(1): 27 37.

53. Flaherty M, Szuster B, Miller P (2000) Low salinity inland shrimp farming in Thailand. Ambio 29(3): 174-179.

54. Dewalt BR, Vergne P, Hardin M (1996) Shrimp aquaculture development and the environment: people, mangroves and fisheries on the Gulf of Fonseca, Honduras. World Dev 24(7): 1193-1208.

55. Funge-Smith SJ, Briggs MRP (1998) Nutrient budgets in intensive shrimp ponds: implications for sustainability. Aquaculture 164(1-4): 117-133.

56. Islam M, Yasmin R (2017) Impact of Aquaculture and Contemporary environmental issues in Bangladesh. International Journal of Fisheries and Aquatic Studies 5(4): 100-107.

57. Patil PG, Krishnan M (1998) The social impacts of shrimp farming in Nellore District, India. Aquac Asia 3: 3-5.

58. Dierberg FE, Kiattisimkul W (1996) Issues, impacts, and implications of shrimp aquaculture in Thailand. Environ Manag 20(5): 649-666.

59. Ali AMS (2006) Rice to shrimp: land use/land cover changes and soil degradation in southwestern Bangladesh. Land Use Policy 23(4): 421435 .
60. Primavera JH (1991) Intensive prawn farming in the Philippines: ecological, social and economic implications. Ambio 20(1): 28-33.

61. Alam SMN, Pokrant B, Yakupitiyage A, Phillips MJ (2007) Economic returns of disease affected extensive shrimp farming in southwest Bangladesh. Aquacult Int 15(5): 363-370.

62. Mazid MA, Banu ANH (2002) An overview of the social and economic impact and management of fish and shrimp disease in Bangladesh, with an emphasis on small-scale aquaculture. In: Arthur JR., Phillips MJ, Subasinghe RP, Reantaso MB, MacRae LH (Eds.), Primary Aquatic Animal Health Care in Rural, Small-scale, Aquaculture Development. FAO Fisheries Technical Paper No. 406.

63. Uddin SA, Kader MA (2006) The use of antibiotics in shrimp hatcheries in Bangladesh. J Fish Aquat Sci 1: 64-67.

64. Gräslund S, Bengtsson BE (2001) Chemicals and biological products used in southeast Asian shrimp farming, and their potential impact on the environment - A review. Sci Total Environ 280(1-3): 93-131.

65. Rahman MM, Giedraitis VR, Lieberman LS, Akhtar MT, Taminskiene V (2013) Shrimp cultivation with water salinity in Bangladesh: the implications of an ecological model. Univ Public Health 1(3): 131-142.

66. Islam A (1999) Effects of shrimp farming on the physicochemical and biological qualities of water. Bangladesh Agriculture University, Mymensingh.

67. Hagler M (1997) Shrimp: the devastating delicacy, Green peace report, Greenpeace.

68. Ghafur A, Kamal M, Dhaly MR, Khatun S (1999) Socio-economic and environmental impact of shrimp culture in south-western Bangladesh: an integrated approach. Nijera Kori and IDPAA at Proshika, Dhaka.

69. Manju T (1996) Political economy of shrimp culture in Bangladesh, poverty research report 13, report prepared for the Grameen Trust, Grameen Trust, Grameen Bank, Dhaka.

70. Deb AK (1997) Fake blue revolution: environmental and socioeconomic impact of shrimp culture in the coastal areas of Bangladesh. Ocean \& Coastal Management 41(1): 63-88

71. Anwar MS (2003) Effect of shrimp culture on ecology in the coastal areas of Bangladesh. Human Landscape Ecology, (MNFEL 330).

72. Didar-Ul Islam SM, Bhuiyan MAH (2016) Impact scenarios of shrimp farming in coastal region of Bangladesh: an approach of an ecological model for sustainable management. Aquaculture International 24(4): 1163-1190.

73. Toufique KA (2000) Impact of Structural Adjustment Policies on the Environment in Bangladesh. Bangladesh Institute of Development Studies, Dhaka.

74. Ministry of Water Resources (2005) Coastal Zone Policy. Ministry of Water Resources, Dhaka.

75. Afroz T, Alam S (2013) Sustainable shrimp farming in Bangladesh: A quest for an Integrated Coastal Zone Management. Ocean \& Coastal Management 71: 275-283. 
Your next submission with Juniper Publishers will reach you the below assets

- Quality Editorial service

- Swift Peer Review

- Reprints availability

- E-prints Service

- Manuscript Podcast for convenient understanding

- Global attainment for your research

- Manuscript accessibility in different formats ( Pdf, E-pub, Full Text, Audio)

- Unceasing customer service

Track the below URL for one-step submission https://juniperpublishers.com/online-submission.php 